\title{
Element Content of Bryophytes
}

GEOLOGICAL SURVEY BULLETIN 1198-D 
$+1$

a.

(15)

i

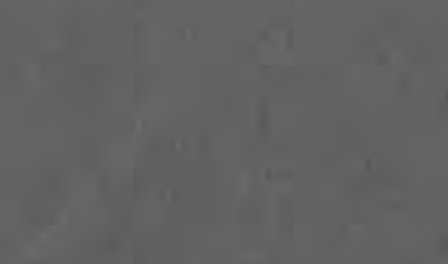

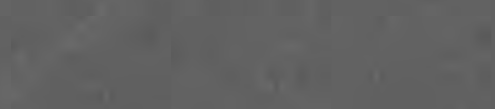

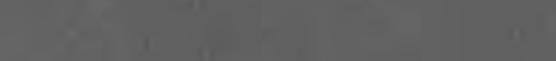

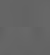

$\cos ^{2}+x^{2}$

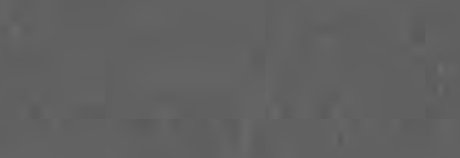

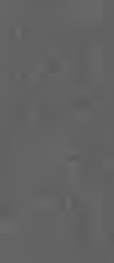

T.

4

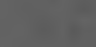

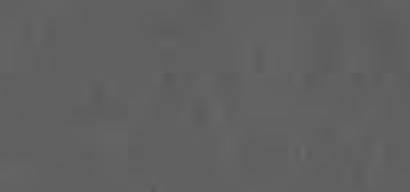

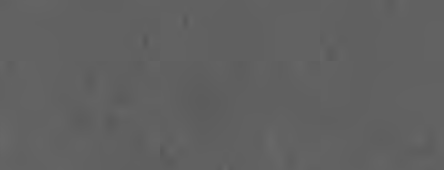

$=$

F

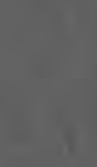

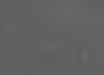

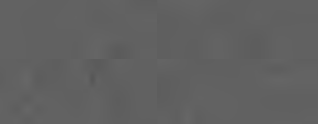

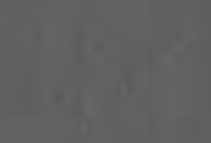

1

$4^{2}$

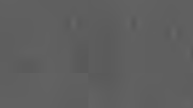

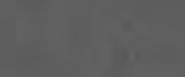

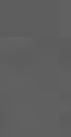

$y_{1}+3$

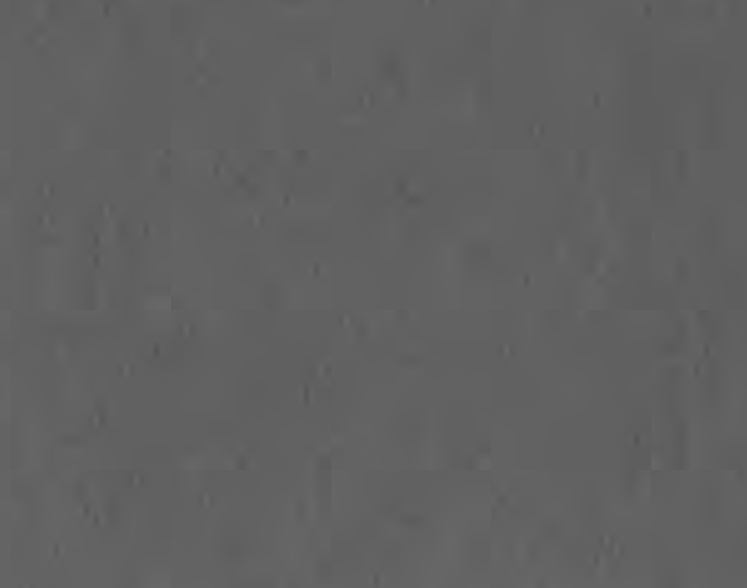




\section{Element Content of}

Bryophytes

$B y$ HANSFORD T. SHACKLETTE

CONTRIBUTIONS TO GEOCHEMICAL PROSPECTING FOR MINERALS

GE OL O I C AL S URVEY B ULLE T I N 1198-D

The amounts of certain elements in mosses and liverworts compared with the amounts in the substrates and in vascular plants

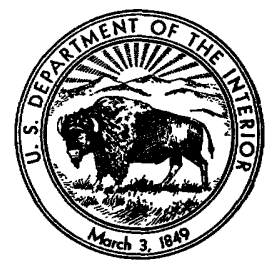




\section{UNITED STATES DEPARTMENT OF THE INTERIOR}

STEWART L. UDALL, Secretary

\section{GEOLOGIGAL SURVEY}

Thomas B. Nolan, Director 


\section{CONTENTS}

\begin{tabular}{|c|c|}
\hline & Page \\
\hline Abstract & D1 \\
\hline Introduction & \\
\hline Review of the literature & \\
\hline Methods & \\
\hline Results. & \\
\hline Analyses of bryophytes and their substrates & \\
\hline Comparison of the elements in bryophytes and vascular plants & \\
\hline Elements looked for but not found in plant samples. & \\
\hline Elements that occur in plants, but which were not determined in this & \\
\hline & \\
\hline Summary of element content of bryophytes. & \\
\hline of results & \\
\hline e contamination & \\
\hline Correspondence of these data to those of other reports & \\
\hline (1) & \\
\hline (a) & \\
\hline
\end{tabular}

\section{ILLUSTRATION}

Figure 1. Species of bryophytes that are representative of the groups included in this study.....

\section{TABLES}

TABLE 1. Element content of bryophytes (percent of ash) and of the substrates (percent of dry weight) on which they grew.. In pocket

2. The occurrence and contents of certain elements in bryophytes

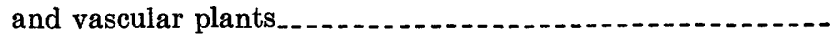





\title{
CONTRIBUTIONS TO GEOCHEMICAL PROSPECTING FOR MINERALS
}

\section{ELEMENT CONTENT OF BRYOPHYTES}

\author{
By Hansford T. Shacklette
}

\begin{abstract}
Thirty-eight samples of liverworts and mosses and the substrates on which they grew were analyzed for 33 elements by colorimetric, chemical, and spectrographic methods. Average percentages of these elements in ash of the bryophytes are $\mathrm{Ag}, 0.0009 ; \mathrm{Al}, 4.2 ; \mathrm{B}, 0.0093 ; \mathrm{Ba}, 0.4648 ; \mathrm{Be}, 0.0006 ; \mathrm{Bi}, 0.003 ; \mathrm{Ca}, 9.1 ; \mathrm{Ce}$, 0.042 ; Co, 0.0032 ; Cr, 0.0079 ; Cu, 0.0204; Fe, 2.08; Ga, 0.0018; I, 0.0005; K, 4.2; $\mathrm{La}, 0.009 ; \mathrm{Mg}, 1.97 ; \mathrm{Mo}, 0.0012 ; \mathrm{Mn}, 0.3058 ; \mathrm{Nb}, 0.005 ; \mathrm{Nd}, 0.02 ; \mathrm{Ni}, 0.0083 ; \mathrm{P}$, $0.96 ; \mathrm{Pb}, 0.186 ; \mathrm{Sc}, 0.001 ; \mathrm{Sn}, 0.002 ; \mathrm{Sr}, 0.0451 ; \mathrm{Ti}, 0.196 ; \mathrm{V}, 0.0071 ; \mathrm{Y}, 0.005$; $\mathrm{Yb}, 0.0006 ; \mathrm{Zn}, 0.152 ; \mathrm{Zr}, 0.0124$. Elements looked for in all or some of these bryophyte samples but which were not found are $\mathrm{As}, \mathrm{Au}, \mathrm{Cd}, \mathrm{Dy}, \mathrm{Er}, \mathrm{Eu}, \mathrm{Gd}, \mathrm{Hf}$, Hg, Ho, In, Li, Lu, Pd, Pr, Re, Sb, Sm, Ta, Tb, Te, Th, Tl, Tm, U, and W.

In this study 1,501 samples of vascular plants (ferns and seed plants) from the same regions as those where the bryophytes grew were also analyzed by the same methods, and the average content of the same elements are presented. Bryophytes contained greater percentages of 13 elements than did vascular plants, lesser percentages of 15 elements, and approximately the same percentages of 3 elements. Niobium and scandium were found in measurable amounts in bryophytes but were not present in vascular plants; cadmium, lithium, and rhenium were found in vascular plants but were not found in bryophytes.

Frequency of occurrence and amounts of most minor elements differ greatly in bryophytes and vascular plants. Bryophytes have a lesser amount of the macroelements $\mathrm{Ca}, \mathrm{Mg}, \mathrm{K}$, and $\mathrm{P}$ than have the vascular plants. A bryophyte sample is more likely to contain a greater number of elements in measurable amounts than is a vascular plant sample. The content of an element in bryophytes generally is related to the content of the same element in the supporting substrate only if the substrate contains the element in greater than normal amounts; but bryophytes can concentrate certain elements, including the rare earths, even where they grow on substrates in which the elements were not detected. Extremely high percentages of five elements in the ash of certain bryophyte samples were noted : $\mathrm{Ba}, 5.0 ; \mathrm{Cu}, 0.2 ; \mathrm{Pb}, 2.0 ; \mathrm{Sr}, 0.15 ;$ and $\mathrm{Zn}, 2.0$. These concentrations, however, did not produce visible toxicity symptoms in the bryophytes. The high concentration of these elements in the bryophytes is not due to contamination of the samples by their substrates; the substrates contained less of the element than was found in the plant ash. Bryophyte samples that contained maximum amounts of each of the elements actually grew on substrates that contained smaller percentages of the elements than did the bryophyte ash. Be, La, Ti, and $\mathrm{Zr}$ were more abundant in the substrates than they were in the plant ash. The ability of bryophytes to concentrate 27 elements is thus demonstrated.
\end{abstract}


This study was not extensive enough to conclusively demonstrate distinctive patterns of element absorption by bryophyte taxa, although there were indications that these patterns may exist.

\section{INTRODUCTION}

Bryophytes have been less frequently sampled for chemical analysis than have vascular plants because of their lack of value as forage plants and the difficulty of their identification. Reports of bryophyte analyses are sparse in botanical, chemical, geological, and other literature. Most biogeochemical samplers are less familiar with bryophyte species than with the flowering plants and have therefore neglected bryophytes as sampling media. Although bryophytes occasionally have been used as indicator plants in mineral prospecting, the ofttimes indefinite connection of some species to their substrates, the species' primitive or nonexistent vascular system, and the ectohydric nature of many species do not suggest that their content of elements would faithfully reflect the chemical composition of their substrates.

In spite of these characteristics of bryophytes, the few writers to comment on the element content of bryophytes have found the content to resemble that of vascular plants. Garjeanne (1932, p. 210-211) wrote, "A fairly large number of analyses of different species has been made and though all contain the normal elements, they show great specific and individual differences. *** The inorganic elements found in Bryophytes do not differ essentially from those of the higher plants." Lounamaa $(1956$, p. 183) stated, "The trace element content of mosses resembles most closely that of the higher plants; in comparison with lichens the large amount of manganese is remarkable."

When I conducted geochemical studies during 1962 and 1963 in Wisconsin and adjacent States and in Missouri and Kentucky, I sampled a great variety of plants that were analyzed for their element content. (From 1,553 samples, 160 species were identified including algae, bryophytes, ferns and their allies, and seed plants.) Various plant organs were sampled including stems, leaves, wood, fruits, and entire plants, as appropriate for the plant species. The samples were collected in rural areas remote from cities or factories. They were mostly of native, noncultivated plants growing in forests or prairies little disturbed by man. Thirty-eight bryophyte samples were collected, and these provided a basis for comparison of the element content of bryophytes and vascular plants that grew in the same environment. Samples of the substrates on which the plants grew were also collected and similarly analyzed to permit a study of the plant-soil relationship.

The nomenclature used in this report is that used by Welch (1957) for the mosses and that used by Evans (1940) for the liverworts. 
Thanks are extended to my field assistants John R. Keith and David H. Pryor, to my laboratory assistants Jessie M. Bowles and David D. Reid, and to the chemists of the U.S. Geological Survey laboratories in Denver, Colo., for their part in this work.

\section{REVIEW OF THE LITERATURE}

Treffner (1881) published the most comprehensive of the early analytical studies of true mosses, but he dealt principally with the organic compounds found in these plants. He did not give their content of the separate elements, but he did list the ash content as percentage of dry weight of 10 species, as follows:

$\begin{array}{lll}\text { Polytrichum commune_- 2.698 } & \text { Mnium affine_-_-_-_- } & 6.39 \\ \text { Sphagnum cuspidatum_- } 1.93 & \text { Funaria hygrometrica--- } & 5.56 \\ \text { Hypnum splendens_-_-_ 2.35 } & \text { Schistidium apocarpum_- } & 4.54 \\ \text { Orthotrichum anomalum_ 3.48 } & \text { Climacium dendroides_-- } & 3.63\end{array}$

The compounds present in mosses and liverworts that protect them from being eaten by animals were investigated by Stahl (1888); however, the element content of these plants was not given. Church $(1888$, p. 126) analyzed the moss Fontinalis antipyretica and reported that it contained 2.82 percent alumina $(1.49$ percent $\mathrm{Al})$ and 24.53 percent silica (11.46 percent $\mathrm{Si}$ ) in ash and had 4.76 percent ash in the dry plant. Kohl (1889, p. 201), in his study of calcium and silica in plants, attributed to contamination any silica content in bryophytes greater than 15 percent.

Lohmann (1903, p. 222-226) made the first quantitative report of elements in liverworts, including four species, and the percentages of ash in five species. Although he found iodine in liverworts, he did not attempt to determine the quantity. He discussed the fact that animals of all kinds ordinarily do not eat bryophytes, and he presented experimental evidence to show that the plants are thus protected mostly by their content of organic compounds that serve as animal repellents. Lohmann (1903, p. 214-215) wrote [translated],

It is a striking and very well known fact that bryophytes in general are willingly eaten by neither insects, snails, nor larger animals. ${ }^{*} *$ In Stahl's feeding experiments some species of mosses were found to be so hard that, in spite of their mild taste, very hungry snails would scarcely damage them. ***A number of liverworts have a characteristic more or less penetrating odor and a sharp or bitter taste.

The protective mechanisms of mosses and liverworts were contrasted by Stahl $(1888$, p. 662) as follows [translated]:

A greater contrast can scarcely be imagined than that which exists between the representatives of the two groups of bryophytes-the mosses and the liverwortsin respect to the development of their protective devices. In the former this protection is probably exclusively mechanical, while in the latter this protection 
is principally chemical. Both kinds of defense therefore substitute for one another in the two subdivisions of the Class Bryophyta.

The early reports of bryophyte analyses were reviewed and summarized by Czapek (1905, p. 814-815). From these reports he compiled a list of the ash content of some bryophytes, as follows: 5 liverwort species, $3-9$ percent (excluding an extreme value of 48.07 percent in a calcite-incrusted sample) ; 2 sphagnum samples, 2.88-3.00 percent; and 3 hypnaceous mosses, $2.32-3.92$ percent. He also tabulated the elements in the ash of these samples as oxides which $\mathrm{I}$ converted to percentages of the elements, as follows:

\begin{tabular}{|c|c|c|c|c|c|c|c|c|c|c|}
\hline Plant & $\mathrm{Mn}$ & $\mathrm{Ca}$ & $\mathrm{Mg}$ & $\mathbf{K}$ & $\mathrm{Na}$ & $\mathbf{P}$ & $\mathbf{S}$ & $\mathrm{Cl}$ & $\mathrm{Si}$ & $\mathrm{Fe}$ \\
\hline $\begin{array}{l}\text { Mastigobryum trilobatum } \\
\text { Fegatella conica } \\
\text { Marchantia polymorpha } \\
\text { Metzgeria furcata } \\
\text { Sphagnum sp. } \\
\text { Hypnum schreberi } \\
\text { Hylocomium splendens } \\
\text { H. triquetrum }\end{array}$ & $\begin{array}{r}0.4 \\
\text { Trace } \\
\text { Trace } \\
\text { Trace } \\
\\
\hdashline\end{array}$ & $\begin{array}{r}5.3 \\
16.7 \\
15.9 \\
9.5 \\
9.9 \\
.8 \\
10.2 \\
11.3 \\
14.9\end{array}$ & $\begin{array}{l}2.4 \\
5.2 \\
6.5 \\
2.9 \\
4.2 \\
4.7 \\
4.6 \\
5.7 \\
4.3\end{array}$ & $\begin{array}{l}50 \\
30.4 \\
28.5 \\
20.5 \\
14.7 \\
19.6 \\
24.9 \\
23.7 \\
15.3\end{array}$ & $\begin{array}{r}1.5 \\
4.7 \\
2 \\
1.3 \\
6.3 \\
8.3 \\
22.2 \\
21.2 \\
13.5\end{array}$ & $\begin{array}{r}3.5 \\
3.4 \\
3.7 \\
2.2 \\
2.4 \\
2.8 \\
5.4 \\
12.6 \\
8\end{array}$ & $\begin{array}{l}3.6 \\
5.3 \\
4.2 \\
3.5 \\
2.4 \\
2.6 \\
2.7 \\
2.4 \\
1.6\end{array}$ & \begin{tabular}{|c|}
1 \\
2.4 \\
2.3 \\
2.0 \\
2.2 \\
2.4 \\
\\
\\
\end{tabular} & $\begin{array}{r}2.3 \\
2.4 \\
1.6 \\
12.8 \\
5.7 \\
7.4 \\
7 \\
3.3 \\
10.8\end{array}$ & $\begin{array}{r} \\
13.5 \\
4.3 \\
5.7 \\
1.5 \\
5.2\end{array}$ \\
\hline
\end{tabular}

Czapek (1905, p. 815) said [translated],

Insofar as the actual material permits a summarized evaluation, the ash content of bryophytes is mostly low. Only the leafy thalli of liverworts are analogous to the foliage leaves of the higher plants in their high values of mineral content. The potassium and phosphoric acid content are mostly found to be high; the thallose liverworts are similar to foliage leaves in their content of these materials. However, the magnesia content of liverworts appears to be somewhat higher in relation to the lime content than in foliage leaves. Lime incrustations and deposits of iron are not rare on bryophytes.

The nitrate content of a moss, Hylocomium triquetrum, was reported by Czapek $(1905$, p. 218$)$ to be 0.0055 percent of the dry weight. This content contrasts greatly with that reported by Czapek for nitrate in some vascular plants: for example, Triticum sativum, $0.95 ;$ Prunus domestica (young sprouts), 0.012 percent; and Solanum tuberosum, 1.54 percent. Waksman and Tenney $(1928$, p. 156) gave the ash content of Sphagnum sp. as 5.01 percent of dry weight, and the crude protein content as 5.5 percent (which indicates a rather high nitrogen content) ; but they did not give element analyses. Griggs (1936), in his study of leafy liverworts on the raw volcanic ash from the Mount Katmai (Alaska) eruption, concluded that these plants could thrive with only very small amounts of nitrogen in their substrate. Griggs and Ready (1934, p. 274) cultured these Mount Katmai liverworts and reported 3,380 ppm (parts per million) organic nitrogen in dry specimens of Cephaloziella byssacea (Roth.) Warnst.

Hutchinson (1953, p. 134-135) stated, in regard to aluminum analyses, "The data relating to the Bryophytes is meagre and for the most 
part unsatisfactory." He cited the analytical results of studies by five other workers who found that aluminum in these plants ranged from 0.1 percent in the ash of Sphagnum palustre L. to 24.4 percent in the ash of Leptodontium aggregatum.

Salmi $(1950$, p. 9), in his study of trace elements in peat, reported the analyses (in percent) of a "Bryales-Sphagnum" peat from Finland as follows: $\mathrm{Sn}, 0.01 ; \mathrm{Pb}, 0.06 ; \mathrm{Mn}, 0.1 ; \mathrm{Co}, 0.01$; and $\mathrm{Ni}, 0.1$. He emphasized, however, that these amounts may represent mineral accumulation by the peat over thousands of years, and that the amounts are not necessarily representative of the mineral content of the living plants. Mayer and Gorham (1951) analyzed 19 moss species from the Lake District of England and reported 0.005-0.4 percent iron and $0.005-0.13$ percent manganese in dry weight of these plants. They wrote (Mayer and Gorham, 1951, p. 250), "This group of plants shows a striking tendency to accumulate iron, the highest figure being 400 $\mathrm{mg}$ [per $100 \mathrm{~g}$ dry weight]. Over half the iron values are above the maximum recorded for manganese, which is $77 \mathrm{mg}$ for a sample of Plagiothecium elegans from conifer wood."

Analyses of the moss Hylocomium splendens were made by Tamm $(1953$, p. 80$)$, and the changes in the phosphorus, potassium, nitrogen, and calcium contents associated with increasing age of the plants were summarized as follows:

From these data we can conclude that the univalent elements potassium and sodium are accumulated in the young moss and then decrease in concentration, sodium very quickly, potassium at a slower rate. The bivalent and trivalent metals show a successive accumulation from year to year in most segments [of the moss plant], with or without a previous accumulation in the bud. Aluminum, which is not considered as necessary, appears to behave as the indispensable element iron.

Tamm claimed that the annual shoots of this moss are nutritionally isolated, both from each other and from the soil, and that the plant receives its supply of mineral nutrients from rainwater that has passed through tree crowns and has thereby leached out the soluble nutrients from the leaves and bark. He suggested also that the moss may absorb gaseous ammonia directly from the air, because the amount absorbed seemed too great to have come only from rainwater.

Lounamaa (1956), in his study of trace elements in plants growing wild on different rocks in Finland, analyzed 9 species of mosses for 15 elements and related the differences in analyses to the chemical characteristics of the rocks on which they grew. He summarized his results as follows $(1956$, p. 73 and 79$)$ :

The low content of certain elements in mosses (gallium, yttrium, cadmium, and lead) as compared to their occurrence in lichens warrants attention. *** On 766-982-65-2 
the other hand, mosses contain more boron and manganese than lichens do. $* * *$ Even on the basis of a material as limited as this, it becomes evident that difference of habitat has a significance on the trace element content of mosses. Thus moss samples gathered from ultrabasic rocks contain more chromium, cobalt, and nickel than those originating from other kinds of rocks, both in comparing representatives of the same species, and in general. *** The content of manganese, gallium and zirconium is relatively high, again, in mosses growing on silicic rocks, according to observations made in the present study. The samples taken from calcareous rocks, which, with the exception of zirconium, did not reveal a content of any trace element exceeding that in mosses growing on other rocks, attracted attention particularly by their paucity of chromium, nickel, silver and lead. On the basis of the present material it may be stated that no very great differences between the various species of mosses are to be observed in respect to their content of trace elements.

A beryllium content of about 0.001 percent in a moss (species not given) that had grown over a pegmatite vein containing beryllium was reported by Zalashkova and others $(1958$, p. 12). This amount was in the same range of values (0.001-0.0039 percent) as was reported for vascular plants, with which the moss grew. In this paper the authors described the role of vascular plants in the enrichment of beryllium in soil. This process of enrichment is of particular importance in explaining the source of many elements absorbed by terrestrial bryophytes and was described as follows (Zalashkova and others, 1958, p. 11) [translated]:

If one may judge by the results obtained, beryllium is accumulated in important quantities in the leaves of woody plants and in certain herbs that have grown above the rocks that are enriched to a certain degree in beryllium. *** The results of these researches on the ash of plants permit an explanation to be made of the selective accumulation of beryllium in soil and subsoil and its absence in the deeper horizons of the transported alluvial and diluvial deposits. Thus the role of vegetation as an agent contributing to the transport and accumulation of beryllium in the soil and subsoil is shown very clearly. Similarly, herbs and the leaves of woody plants play a particularly important role because each year they are the principal factors of beryllium concentration in the process of soil formation.

The ash of five samples of mosses (species not given) from a mineralized stream was reported by Cannon (1963, p. 197) to contain $200 \mathrm{ppm}$ vanadium. She reported the average vanadium content of 11 other categories of vegetation to range from 7 to $98 \mathrm{ppm}$; thus, the mosses contained more than twice as much of this element as was found in other plant groups. The unique habitat of the mosses, however, may have accounted for their great vanadium values. Mrs. Cannon found three species of vascular plants, classified as vanadium accumulators, that contained from 560 to $900 \mathrm{ppm}$ vanadium in ash.

Willis (1964, p. 674-676) reported his analyses of shoots of the moss Tortula ruraliformis, but he gave only the amounts of the organic compounds that were found. His calculations showed that the ash 
content of shoots of this plant range from 5.7 to 6.2 percent of the dry weight.

Malyuga (1964, p. 23), in his extensive treatment of biogeochemical methods of prospecting, gave an analysis of only one moss, Scorpidium scorpioides, which contained 0.016 percent uranium; yet, he determined that the soil in which it grew contained only 0.0065 percent of this element. Analyses of other elements in this moss were not given.

\section{METHODS}

Samples of bryophytes that are virtually free of contaminants are difficult to obtain. The problem of contamination was stated by Garjeanne (1932, p. 219) as follows: "The chief difficulty in analysing the ash of Bryophytes is to obtain pure material. This difficulty is greater in liverworts which often adhere tightly to the substratum. It is therefore possible to find too much $\mathrm{Ca}$ and $\mathrm{Si}$, or even $\mathrm{Al}$, which may have been derived from incrustations of Ca salts or of clay." Lounamaa $(1956$, p. 68) encountered the same problem in his studies and said, "The moss material is so limited because experience showed that a pure moss specimen is exceedingly difficult to obtain."

Acrocarpous mosses (fig. $1 C$ ) are often firmly attached to the substrate by masses of rhizoids that tenaciously hold particles of soil or organic substrate; in addition, the very dense polsters that are formed by some species (for example, in the Grimmiaceae) frequently accumulate large quantities of windblown soil and rock particles. Barkman (1958, p. 101) discussed the effect of this dust accumulation on the occurrence of cryptogamic epiphytes, but he did not give chemical analyses of these plants. The thallose liverworts (fig. $1 \mathrm{~A}$ ) generally are firmly attached to soil or rock surfaces by abundant rhizoids, and only with difficulty can they be freed of inorganic particles. Some of the pleurocarpous mosses (fig. $1 D$ ) and leafy liverworts (fig. $1 B$ ), on the other hand, form extensive mats that have only slight rhizoidal attachment to the substrate; therefore, samples of these plants may be relatively free of contaminants.

The first group of bryophyte samples that I collected for chemical analysis was cleaned by washing in flowing spring water near the sites where they grew. This cleaning method was a tedious process; as much as 45 minutes was required to clean enough plants for a 10-gram dry sample. Even after such careful washing, the samples, when ashed, were found to be contaminated. This contamination is shown by some of the very high ash values in table 1 . Thereafter, I cleaned the samples in the laboratory using the following procedure.

The samples were oven dried at $80^{\circ} \mathrm{C}$ for 48 hours; then the dense moss polsters and mats were teased apart by hand. The material was 

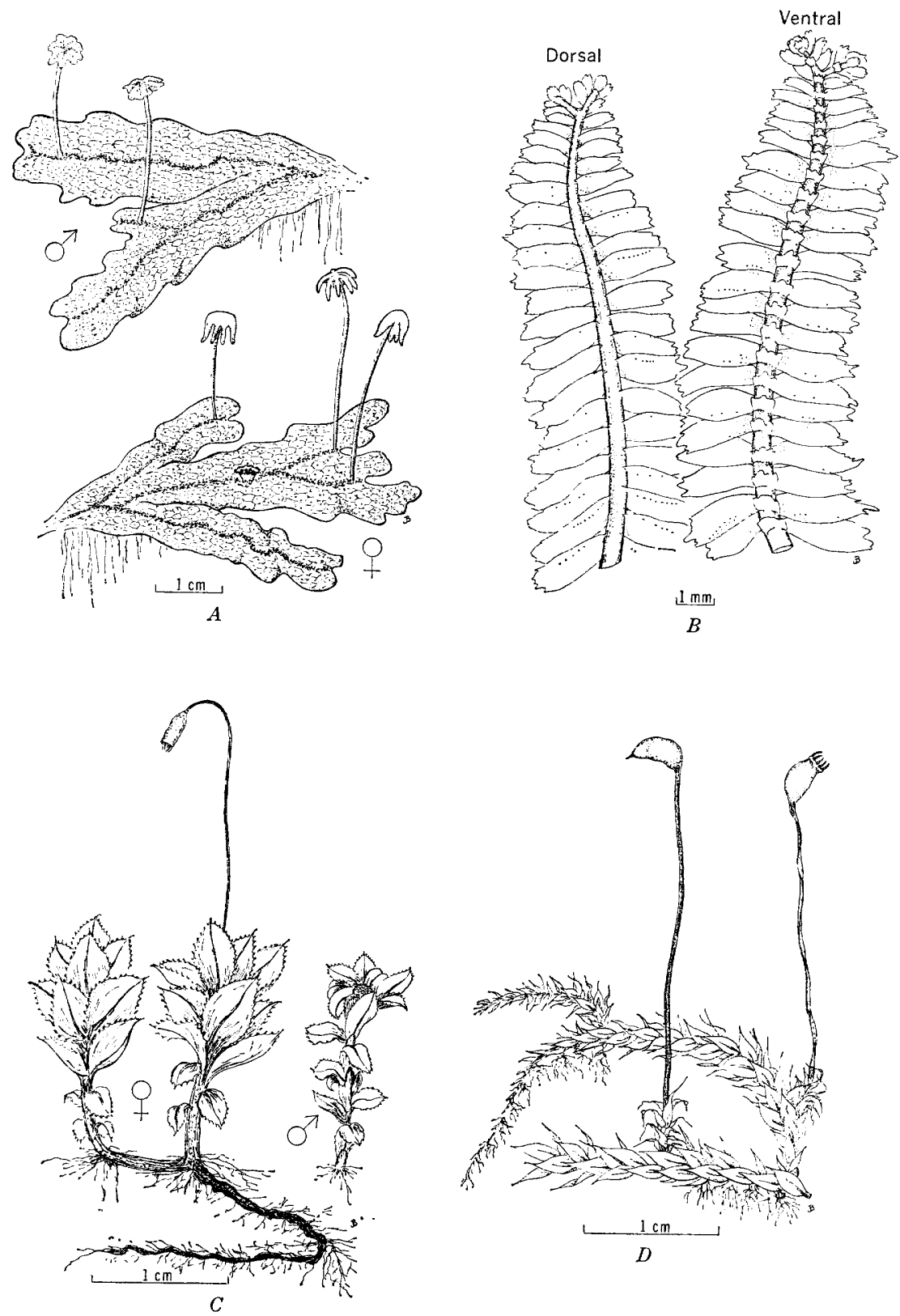

FIGURE 1.-Species of bryophytes that are representative of the groups included in this study $\left(\sigma^{*}\right.$, male; $q$, female) : $A$, thallose liverwort (Marchantia polymorpha); $B$, leafy liverwort (Bazzania trilobata); $C$, acrocarpous moss (Mnium affine); $D$, pleurocarpous moss (Brachythecium rutabulum). 
placed in a medium-fine ( 50 mesh per in.) top-and-bottom sieve and blown with compressed air for 5 minutes to thoroughly agitate the plants and remove many of the larger particles of soil and rock. The sample was then washed with high-pressure tapwater for 10 minutes in a double-thickness cheesecloth bag that was being kneaded vigorously. This treatment was followed by washing the sample in flowing demineralized water for 5 minutes and then drying it in the oven as before. The dried sample was transferred to a fine mesh (100 mesh per in.) top-and-bottom sieve and blown with compressed air for 10 minutes. The relatively pure sample was then ground in a Wiley mill and pulverized in a Waring Blendor. This procedure was used for all bryophyte samples listed in table 1 that have the laboratorynumber prefix D404.

Part of the pulverized sample was then transferred to a ceramic crucible, weighed, and burned to ash in an electric oven in which the heat was increased $50^{\circ} \mathrm{C}$ per hour to a temperature of $550^{\circ} \mathrm{C}$ and held at this temperature for 14 hours. The ash was then weighed to determine the ash yield of the dry plant sample.

Soil samples were air dried and passed through a 200 -mesh stainless steel sieve; then the -200 fraction was analyzed. Rock samples were crushed, pulverized in a ceramic mill, and then sieved in the same manner as were the soils.

Contents of calcium, potassium, phosphorus, and zinc in all samples were determined by the colorimetric methods described by Ward and others (1963). The other elements (except iodine in plant samples) were determined by semiquantitative spectrographic analysis after the ash of plant samples had been diluted with an equal weight of matrix composed of sodium silica ( 10 percent $\mathrm{Na}$ ). The values were reported in percent to the nearest number in the series $1,0.7,0.5,0.3,0.2,0.15$, and 0.1 , and so on, which represent approximate midpoints of group data on a geometric scale. The assigned group for semiquantitative results includes the quantitative value about 30 percent of the time.

Spectrographic analyses of all plant samples were performed on the same apparatus by the same operators, and the minimum detection values were identical in all analyses for an element except those for cerium. In the analyses for cerium the spectral lines of certain other elements (principally calcium, but also vanadium and niobium) in the matrix or in the sample sometimes prevented the normal evaluation of the cerium lines. Soil and rock spectrographic analyses were performed in two separate laboratories with different apparatus. The methods of analysis used by the two laboratories had different minimal detection limits for some elements; moreover, these limits sometimes varied in the same laboratory because of certain chemical characteris- 
tics of the sample. Analyses of rocks and soils given in table 1, therefore, are those reported by the laboratories.

Iodine content was determined by ashing the pulverized plant sample by ignition in a closed oxygen-filled flask (to prevent excessive loss of iodine), following the method of Schöniger (1955). The residue in the flask was then analyzed by the ceric sulfate method (Rogina and Dubravcic, 1953). The combination of these methods for plantiodine analysis was devised by Cuthbert and Ward (1964). Slight losses of iodine occur during the ignition, but they do not exceed 10 percent. Iodine content of soils and rocks was not determined.

\section{RESULTS}

\section{ANALYSES OF BRYOPHYTES AND THEIR SUBSTRATES}

The most striking relationship shown in table 1 is the greater content of most elements in the bryophytes than in the substrates on which they grew. When analyses of plant-soil pairs are compared, the content of elements in the bryophyte ash is found to be higher in 62 percent of the comparisons, the contents of bryophyte and substrate are the same in 19 percent, and the content of the substrate is greater than that of the bryophyte in 19 percent. If niobium, scandium, silver, tin, gallium, neodymium, bismuth, beryllium, ytterbium, molybdenum, and lanthanum (the elements that are rarely present in vascular plants) are not considered, the bryophyte has the greater element content in 79 percent of the plant-substrate comparisons, and the substrate content is greater than the bryophyte content in only 15 percent of the comparisons. Five elements of those that were studied (beryllium, lanthanum, molybdenum, titanium, and zirconium) more commonly occur in greater amounts in the substrates than in the bryophyte samples.

Unusually large percentages of barium, copper, lead, strontium, and zinc are reported for some bryophyte samples. These larger values are not due to contamination of the plant samples by the substrate, as the substrate values are smaller. In some samples, however, these values may be related to greater than usual concentration of the elements in the substrate. In other samples large amounts of these elements had accumulated, although the substrate contained only small amounts of these same elements. The living bryophytes that had these large contents of elements showed no toxicity symptoms, although copper, lead, and zinc often have been reported to be poisonous when large amounts are available to plants.

The chemical composition of the substrates differs greatly, but in general the soils have a greater content of the minor elements than have the rocks. I attribute this enrichment of the upper soil horizons to the action of plants, which concentrate these elements and then, 
by decomposition, release them into the surface soil. This process of concentration was called the Goldschmidt enrichment principle by Rankama and Sahama (1955, p. 333-334). A specific example of beryllium enrichment has already been given in this paper.

Such enrichment, however, did not occur for all elements considered in this study. Cerium, molybdenum, neodymium, niobium, and ytterbium were not found in measurable amounts in any soil sample, although they were found in some of the rock and bryophyte samples. Bismuth was not found in either soil or rock samples but was measurable in three plant samples. The rare earth elements neodymium and ytterbium were found in felsite and arkosic sandstone but not in limestone, dolomitic limestone, chert, granite, or quartzose sandstones.

The average contents of cobalt, copper, lead, molybdenum, nickel, and zinc were greater in rock samples than in soil samples; however, many of the soils studied are allochthonous and therefore were not necessarily derived from the rocks that were analyzed; thus, their element contents cannot be directly compared. These elements were generally more concentrated in bryophytes than in their substrates. This observation does not indicate that bryophytes play a primary role in element enrichment of zonal soils-vascular plants, particularly trees and shrubs, undoubtedly transport far greater amounts of these elements from the soil parent material to the soil surface than do bryophytes. Many bryophytes, on the other hand, are characteristic colonizers of rock surfaces and lithosols, and these plants may be concentrators of many of the elements that are added to soils in the early stages of soil development.

A positive correlation often exists between the amount of an element in the substrate and the amount in the bryophyte tissue. This relationship is particularly noticeable in the upper range of values in bryophytes. If the content of an element in the substrate is only average or lower, the correlation is less evident or disappears entirely.

If we consider only the bryophyte samples with the largest concentration of each element and their respective substrates, we get the following plant/substrate ratios:

\begin{tabular}{|c|c|c|c|c|c|}
\hline Ag $\ldots$ & $>15$ & $\mathrm{Fe}_{-}$ & 15 & Sc & 3 \\
\hline $\mathrm{Al}_{\ldots} \ldots \ldots$ & 45 & $\mathrm{Ga}_{\ldots} \ldots$ & 4 & $\mathrm{Sn}_{\ldots} \ldots \ldots$ & $>3$ \\
\hline B & 20 & K & 200 & $\mathrm{Sr}_{\ldots} \ldots$ & 25 \\
\hline $\mathrm{Ba}_{\ldots} \ldots \ldots$ & 200 & La_........... & .4 & $\mathrm{Ti}_{\ldots} \ldots \ldots$ & .07 \\
\hline $\mathrm{Be}_{\ldots} \ldots \ldots$ & .33 & Mg $\ldots$ & 150 & $V_{\ldots} \ldots$ & 7 \\
\hline $\mathrm{Bi}_{\ldots} \ldots$ & $>5$ & Mo $\ldots \ldots$ & $>15$ & $Y \ldots \ldots$ & 13 \\
\hline Ca__._. & 100 & $M n \ldots \ldots$ & 100 & Yb_... & 2 \\
\hline $\mathrm{Ce}_{\ldots} \ldots$ & 1.5 & $\mathrm{Nd}_{\ldots} \ldots$ & 1 & Zn $\ldots \ldots$ & 80 \\
\hline Co_....... & $>20$ & $\mathrm{Ni}$ & 33 & Zr........... & .15 \\
\hline $\mathrm{Cr}_{-} \ldots \ldots$ & 20 & P $\ldots$ & 480 & & \\
\hline $\mathrm{Cu}_{\ldots} \ldots$ & $>400$ & $\mathrm{~Pb}$ & 200 & & \\
\hline
\end{tabular}


Rock asphalt, an uncommon substrate for bryophytes, does not differ greatly from sandstone in its content of the elements listed in table 1; yet the bryophyte species growing on rock asphalt accumulated a larger amount of nickel ( 0.05 percent) than did any bryophyte species growing elsewhere. One of two samples that contained a measurable amount of silver was of this species. One corticolous moss, Thelia asprella, was included in this study. It formed a dense growth on the bark of juniper trees and had no contact with either soil or rock. The juniper tissue contained no measurable amounts of 15 elements and only small amounts of the other elements except calcium, iron, magnesium, phosphorus, and potassium. The bryophyte, however, contained average amounts of eight elements that were not found in the juniper on which it grew. One may suppose that these elements were obtained from windblown material that lodged in the moss mats, from solutes in rainwater, or from the juniper tree, where these elements may occur in amounts too small to be detected by analysis. Whatever the source of the elements, the bryophyte clearly exhibited considerable ability to concentrate these elements.

The existence of characteristic patterns of element absorption by bryophyte species, families, or higher taxa cannot be conclusively demonstrated by these limited data. The thallose liverworts Conocephatum conicum and Marchantia polymorpha seem to be distinctive in that they absorb fewer of the rare elements than do most bryophytes. Both species, however, contain bismuth - an element that is very rare in plants and was found in only one other bryophyte species. These thallose liverworts may also contain greater than average amounts of potassium (as much as 200 times the amount in the substrate), magnesium, and phosphorus; but this absorption pattern is not consistent. In contrast, the leafy liverwort Bazzania trilobata has an elementabsorption pattern more closely resembling that of mosses, except that it contains a very large amount of iron (5 percent). Tin, an element that is very rare in vascular plants, was found only in rock-inhabiting bryophytes of the genera Grimmia and Hedwigia, both in the Grimmiaceae family. Silver, which also is very rarely found in plants, occurred in only two genera, Atrichum and Polytrichum, both in the Polytrichaceae family.

Certain tendencies in element absorption apparently exist in some bryophyte genera. Five samples of Hedwigia ciliata that grew on four different types of rock consistently contained the rare elements scandium, gallium, ytterbium, yttrium, and cobalt. Five samples of species in the genus Polytrichum that grew on both soils and rocks consistently lacked scandium but had a content of the other elements in a typical random pattern. There was insufficient replication of samples to characterize the element absorption patterns of other genera. 

PLANTS

The elements are listed in table 1 in inverse order to their frequency of occurrence in measurable amounts in vascular plants. Thus scandium, gallium, and ytterbium are seen to occur commonly in bryophytes, although these elements are but rarely found in vascular plants. Their presence in the bryophyte samples cannot be attributed to contamination by the substrate, for these elements were either not detected or were found in lesser amounts in the substrates. The elements silver, beryllium, bismuth, lanthanum, molybdenum, niobium, neodymium, and tin are not commonly found in vascular plants and, likewise, are not common in bryophytes, but they do occur more frequently in the latter. Cobalt, vanadium, yttrium, and ytterbium, which occur in 16 percent or less of the vascular plant samples, were found in 86-100 percent of the bryophyte samples. Boron, nickel, and lead, which were detected in 83-97 percent of the vascular plants, were found in 97-100 percent of the bryophytes. The remaining elements, found in 99-100 percent of vascular plant samples, were found in all the bryophyte samples.

Table 2 compares the frequency of occurrence and the percentage in ash of elements in bryophytes and vascular plants. The great disparity in number of samples in the two groups (generally 38 bryophyte samples and 1,501 vascular plant samples) creates a difference in the reliability of the two groups of data. The average amounts of the elements, however, are based only on analyses of those samples in which the particular element was found-not on all the samples that were analyzed for the element. If equal numbers of bryophyte samples and vascular plant samples had been analyzed, the elements that were not found in bryophytes (cadmium, lithium, and rhenium) and are very rare in vascular plants would probably have been detected in a few bryophyte samples. The absence of niobium and scandium, though, seems to be a characteristic of vascular plants and not a sampling error, for these elements were found in 7.9 and 57.8 percent, respectively, of the bryophyte samples.

The elements that are found in both groups of plants may be arranged according to comparative contents.

Contents greater in bryophytes than in vascular plants.-Aluminum, barium, chromium, copper, iron, gallium, nickel, lead, silver, titanium, vanadium, zinc, and zirconium are more abundant in bryophytes than in vascular plants. The greater amounts of aluminum, iron, titanium, and zinc in some samples may be attributed to contamination of the bryophytes by the substrate. Greater values for the other elements cannot be due to this contamination because the substrates contain less of these elements than is found in the plant ash. 
TABLE 2.-The occurrence and contents of certain elements in bryophytes and vascular plants

[Contents are percent of ash]

\begin{tabular}{|c|c|c|c|c|}
\hline \multirow{2}{*}{ Element } & \multicolumn{2}{|c|}{ Bryophytes 1} & \multicolumn{2}{|c|}{ Vascular plants 2} \\
\hline & $\begin{array}{l}\text { Percent of } \\
\text { samples in } \\
\text { which found }\end{array}$ & $\begin{array}{l}\text { A verage content } \\
\text { in samples in } \\
\text { which found }\end{array}$ & $\begin{array}{l}\text { Percent of } \\
\text { samples in } \\
\text { which found }\end{array}$ & $\begin{array}{l}\text { A verage content } \\
\text { in samples in } \\
\text { which found }\end{array}$ \\
\hline $\begin{array}{l}\mathrm{A} \\
\mathrm{B}^{\mathrm{B}} \\
\mathrm{Ba}\end{array}$ & $\begin{array}{c}7.9 \\
100 \\
97.4 \\
100 \\
26.3 \\
7.9 \\
100 \\
0 \\
21 \\
86.8 \\
100 \\
100 \\
100 \\
94.8 \\
100 \\
100 \\
23.7 \\
0 \\
100 \\
7.9 \\
100 \\
7.9 \\
7.9 \\
100 \\
100 \\
100 \\
0 \\
57.8 \\
7.9 \\
100 \\
100 \\
100 \\
89.5 \\
78.9 \\
100 \\
100\end{array}$ & $\begin{array}{l}0.0009 \\
4.2 \\
.0093 \\
.4648 \\
.0006 \\
.003 \\
9.1 \\
-3.042 \\
.0032 \\
.0079 \\
.0204 \\
2.08 \\
.0018 \\
.0005 \\
4.2 \\
.009 \\
-\overline{1.97} \\
.0012 \\
.3058 \\
.005 \\
.02 \\
.0083 \\
.96 \\
.186 \\
. .01- \\
.001 \\
.002 \\
.0451 \\
.196 \\
.0071 \\
.005 \\
.0006 \\
.152 \\
.0124\end{array}$ & $\begin{array}{c}1.5 \\
100 \\
97.5 \\
100 \\
3.1 \\
2.8 \\
100 \\
.1 \\
10.7 \\
8.4 \\
99.7 \\
99.9 \\
100 \\
2 \\
100 \\
100 \\
5.8 \\
100 \\
4.7 \\
100 \\
0 \\
2.1 \\
82.2 \\
100 \\
88 \\
.07 \\
0 \\
1.9 \\
99.5 \\
99.9 \\
14.9 \\
9.8 \\
4.2 \\
99.9 \\
16.4\end{array}$ & $\begin{array}{c}0.0005 \\
.54 \\
.0311 \\
.2524 \\
.0009 \\
.003 \\
23.6 \\
.015 \\
3.053 \\
.0123 \\
.001 \\
.0112 \\
.29 \\
.0011 \\
4.00046 \\
12.7 \\
.017 \\
.05 \\
5.47 \\
.0025 \\
.5144 \\
.037 \\
.0038 \\
1.93 \\
.0111 \\
.15 \\
.0068 \\
.0639 \\
.02 \\
.0023 \\
.0072 \\
.0006 \\
.101 \\
.0035\end{array}$ \\
\hline
\end{tabular}

138 bryophyte samples were analyzed for each element except $I$, for which 34 samples were analyzed.

21,501 samples of vascular plants were analyzed for each element except $\mathrm{Ca}(586), \mathrm{Cu}(1,498) \mathrm{I}(118), \mathbf{K}(580)$ and $P(586)$.

3 Interference from other elements prevented some values being assigned to the normal lower sensitivity limit; these values are averaged as $1 / 2$ the reported value.

4 Percent of dry weight.

5 Contents reported greater than 10 percent are averaged as 15 percent.

6 Analysis of 1 sample only.

Contents approximately the same in both groups.-Bismuth, iodine, and ytterbium contents are approximately the same in both bryophytes and vascular plants. Bismuth is so rare in both groups of plants that the few reports of it may represent contamination; however, the origin of this possible contamination is not readily apparent, for the substrates have far less bismuth than was detected in the plant samples. 
Ytterbium is most certainly contained in the plant tissue, for the substrate samples either contained none of this element or much less than was found in the plant samples. I cannot attach any particular significance to the iodine content of either group, and Shacklette and Cuthbert (in press) suggested that at least part of the iodine content of both groups may have been absorbed from the atmosphere.

Contents greater in vascular plants than in bryophytes.-Beryllium, boron, calcium, cerium, cobalt, potassium, lanthanum, magnesium, molybdenum, manganese, neodymium, phosphorus, tin, strontium, and yttrium were more abundant in vascular plants than in bryophytes. These elements are actually concentrated in the plant tissue, not in the contaminants. This conclusion is based on the assumption that, as groups, the samples of vascular plants are less likely to contain significant substrate contamination than are the bryophyte samples, which $I$ believe is true in the environment where this study was made.

\section{ELEMENTS LOOKED FOR BUT NOT FOUND IN PLANT SAMPLES}

Germanium was detected in some soil and rock samples but not in any plant samples. Gold was not found in soils, rocks, or plants, although $I$ have found it in vascular plants from other areas. Antimony, arsenic, mercury, and uranium were not found in plant samples, but these elements were probably present in some of the samples in amounts below the detection limit of spectrographic analysis, for these elements have been found in other vascular plant samples when more sensitive analytical methods were used. Hafnium, indium, palladium, platinum, tantalum, tellurium, thorium, thallium, and tungsten were looked for in all plant samples but were not found. Samples in which cerium and lanthanum were found were also examined for europium, praseodymium, and samarium without success. If the yttrium content was found to be above 0.005 percent, the sample was examined for erbium, dysprosium, gadolinium, holmium, lutetium, terbium, and thulium; but these elements were not found. Some of these elements do, however, occur in plants, for I have found erbium, dysprosium, gadolinium, holmium, praseodymium, and samarium in vascular plant samples that were collected in other areas.

\section{ELEMENTS THAT OCCUR IN PLANTS, BUT WHICH WERE NOT DETERMINED IN THIS STUDY}

Silicon and sodium were present in the sample matrix used in spectrographic analysis; thus the amounts present in the plant ash could not be determined by this method. Total nitrogen analysis can be accurately made only with fresh plant samples and was not practical in this study. Carbon determinations are not thought by this author 
to be significant in biogeochemical studies because this element is obtained largely from the air and the content in the plant is greatly influenced by changing conditions of metabolism. Analysis of sulfur and chlorine would have been helpful to this study, but the amounts of these elements cannot be determined by the spectrographic methods that were used, and practical considerations prevented their determination by other methods.

\section{SUMMARY OF ELEMENT CONTENT OF BRYOPHYTES}

A total of 43 elements was found in this study or reported in the literature (listed in table 2, in addition to carbon, cadmium, chlorine, hydrogen, nitrogen, oxygen, silicon, sodium, sulfur, and uranium) to occur in bryophytes in measurable quantities. As use of more sensitive analytical methods becomes possible and more species can be sampled, additional elements will probably be added to this list. Of these 43 elements, 16 (boron, calcium, carbon, chlorine, copper, hydrogen, iron, magnesium, manganese, molybdenum, nitrogen, oxygen, phosphorus, potassium, sulfur, and zinc) have been classified as essential for plant growth (Sutcliffe, 1962, p. 6). The 27 remaining elements may be classified as "ballast elements" (Rankama and Sahama, 1955, p. 331) and have no known function in growth and reproduction of plants. In this study 25 elements were looked for but were not found in the bryophyte samples.

\section{DISCUSSION OF RESULTS}

\section{SAMPLE CONTAMINATION}

The problems of sample contamination in soil and plant analysis were presented by Mitchell (1960, p. 555), who stated,

The permissible limit of contamination for any element depends on the ratio of its contents in the sample and in the contaminant, not on its absolute amount in either. $* * *$ If in the element being determined an increase in content resulting from contamination of $5 \%$ of the amount present be acceptable, and this is a very conservative figure better than the normal analytical accuracy, then for an element with a soil/plant ratio of 10 the contaminating soil material must be present at a content of $0.5 \%$ in the dry plant material before difficulties arise. Even in unfavorable conditions this cleanliness should be achieved. It is only for elements with ratios above 100 that due regard must be paid to the possibility of soil contamination in considering the accuracy of analytical results. It is particularly interesting to note that, of the accepted essential plant nutrients, only the Fe determination is readily affected by soil contamination.

Many elements ordinarily are concentrated in plant ash far in excess of the amounts found in the underlying soil or rock. Contamination of the plant sample with soil would decrease these element percentages in the ash; thus the values reported for these elements err only 
by being too low, insofar as soil contamination as a source of error is concerned. These elements are barium, beryllium, boron, calcium, chromium, cobalt, copper, gallium, iron, lead, magnesium, manganese, nickel, niobium, phosphorus, strontium, vanadium, and zinc.

Other elements (aluminum, silicon, titanium, and zirconium), in contrast, often occur in greater amounts in soils than in the ash of plants that grew on the soil; however, rocks may have only a small amount of these elements. Mitchell (1960, p. 555-556) suggested that titanium is the most favorable element for determining the extent of soil contamination. He stated that it has a soil/plant ratio of about 10,000:1 (based on dry weight of the plant-not ash weight) and that values above $5-10 \mathrm{ppm}$ in the dry plant samples are not found in apparently clean material except in some plants such as heather and certain trees. I found, however, that my 1,501 vascular plant samples averaged $15 \mathrm{ppm}$ titanium in the dry plant samples. Most of my samples were from trees and shrubs in which gross contamination is unlikely; only a few samples were from forbs and grasses that grow close to the soil surface. The samples analyzed by Mitchell were presumably from forage plants. My 38 bryophyte samples averaged $297 \mathrm{ppm}$ titanium in the dry sample (15.15 percent in ash), and the substrates averaged $3,000 \mathrm{ppm}$ titanium. If we assume that bryophytes accumulate titanium to the same extent as do vascular plants, the bryophyte samples, on the average, seem to contain a considerable amount of contamination, Nonetheless, several samples reported in table 1 have a higher titanium content than was found in their substrates.

Church (1888, p. 122-123) found that some species of Lycopodium (a fern relative) are aluminum concentrators and have as much as 33.5 percent aluminum in their ash. He suggested that reports of 2 percent or more aluminum in samples of some other plants are inaccurate because of sample contamination. I find, however, that aluminum is present in greater amounts in plant samples in which significant contamination most certainly is not present. In table 2 the data on my bryophyte samples show an average of 4.2 percent aluminum, which is in contrast to a content of 0.54 percent in vascular plants. This large amount of aluminum in some of my bryophyte samples may be partly attributed to contamination, for some substrates contain more than 10 percent of this element; however, some bryophyte samples have 3-10 percent aluminum in their ash, and their substrates contain only 0.15 percent aluminum. Thus we may conclude that, compared to most vascular plants, bryophytes can be classed as aluminum accumulators, although they do not contain as much of this element as was reported by Hutchinson (1943, p. 131-133) to be in Lycopodium and certain other vascular plants. 
The problem of determining contamination in bryophyte samples is not easily solved, for I do not know the nature or origin of the contaminants that may be present-they may be soil, rock particles, humus derived from vascular plants and lichens, dust particles or solutes in rainwater, or drip from overhanging trees. Because of the difficulty of determining the degree and nature of the contamination, I prefer at present to rely most strongly on the percent of ash that is obtained from the burning of the dry sample. Based on my experience in ashing many vascular plant samples as well as this group of bryophyte samples, I consider any bryophyte sample that yields more than 10 percent ash to be probably somewhat contaminated, and any ash percentage in excess of 20 as most certainly representing material extraneous to the bryophyte tissue. Therefore, those samples listed in table 1 that have a very high "ash" percentage must also contain a greater than indicated percentage of the elements that are concentrated in plants, the content of contaminants having, in effect, diluted the elements that are actually in the ash of the plant tissue.

\section{CORRESPONDENCE OF THESE DATA TO THOSE OF OTHER REPORTS}

My data, in general, compare favorably with those quoted by Czapek $(1905$, p. 815$)$ in range of element values. The content of potassium that Czapek reported seems to be too large for some samples-only his lower values fall within the range of the contents that $I$ found. The ash yields of bryophytes that he reported are also in general agreement with my data, if some of my samples that are probably heavily contaminated are eliminated.

Lounamaa (1956, p. 69) tabulated his analyses of 16 bryophyte samples, and these, when I averaged them, gave the following percentages:

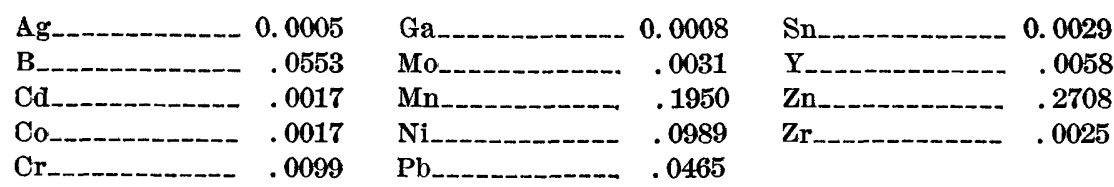

Elements for which these averages differ from mine (table 2) by an order of magnitude are boron, gallium, lead, nickel, and zirconium; the range of values in our analyses, however, generally correspond. Lounamaa found many of his high values on serpentine or other ultrabasic rocks; unfortunately, I do not have any bryophyte samples from these rocks. He reported cadmium values as low as $1 \mathrm{ppm}$, whereas the analytical method used for my samples detects only $50 \mathrm{ppm}$ or more of cadmium. This may explain the lack of cadmium reported for my samples; however, Lounamaa found as much as $100 \mathrm{ppm}$ in two 
bryophyte samples that had been growing on sites of sphaleriteenriched substrates. Schroeder and Balassa $(1963$, p. 819$)$ gave the cadmium content in the wet weight of some vegetables and grains but did not give the percentage of water in these samples. My data are based on ash analyses, with the ash yield of the dry sample also given; thus, our data cannot be directly compared. Schroeder and Balassa also reported a maximum cadmium content in wheat grains to be $0.13 \mathrm{ppm}$. If we assume that these grains contain 10 percent water, this value converts to $0.14 \mathrm{ppm}$ in dry weight. My few samples of vascular plants that contained cadmium average about $10.5 \mathrm{ppm}$ of this element in dry weight, or $150 \mathrm{ppm}$ in ash. This value falls within the range reported by Lounamaa for bryophytes but is much higher than the range of cadmium values in vascular plants reported by Schroeder and Balassa.

\section{CONCLUSIONS}

1. Most minor elements in bryophytes differ greatly in frequency of occurrence or in amount, $c r$ both, from those in vascular plants.

2. Bryophytes have a lesser amount of the macroelements that were included in this study (calcium, magnesium, phosphorus, and potassium) than have the vascular plants. Bryophytes are reported in the literature to also have less nitrogen.

3. A bryophyte sample is likely to contain more elements in measurable amounts than is a vascular plant sample.

4. The content of an element in a bryophyte generally is related to the amount contained in the supporting substrate only if the subtrate has a greater than average amount of that element. The highest content of most elements in bryophytes is in those samples that are collected on substrates that also have a large content of these same elements.

5. Bryophytes concentrate the rare earth elements in their tissues even when growing on substrates in which these elements are not detected.

6. Distinctive patterns of element absorption by bryophyte taxa are indicated in this study, but sampling was not extensive enough to definitely substantiate or refute these indications.

7. Contamination of bryophyte samples by their substrates or by other extraneous material is an obstacle in determining the element content of bryophyte tissue because the contaminant may either impoverish or enrich the sample in certain elements. All investigators have attempted to minimize the effects of contamination by using special cleaning methods. 
8. Large amounts of elements that are generally considered toxic to plants did not produce toxicity symptoms in the bryophytes that contained these elements.

9. Bryophytes are known to be unpalatable to almost all animals. Several students have attributed this to the fact that bryophytes contain certain organic compounds and have mechanical protective devices. Some of the minor elements that typically occur in large quantities in bryophytes, but are rare or absent in vascular plants, may, in addition, repel animals from eating liverworts and mosses.

10. Bryophytes may be useful in regional geochemical evaluations because of their pronounced ability to concentrate the rare earth elements that may not be detected in other sampling media.

\section{LITERATURE CITED}

Barkman, J. J., 1958, Phytosociology and ecology of cryptogamic epiphytes: Assen [Netherlands], Van Gorcum and Co., 628 p.

Cannon, H. L., 1963, The biogeochemistry of vanadium: Soil Sci., v. 96, no. 3, p. 196-204.

Church, A. H., 1888. On the occurrence of aluminium in certain vascular cryptogams: Royal Soc. London Proc., v. 44, p. 121-129.

Cuthbert, Margaret, and Ward, F. N., 1964, Determination of iodine in vegetation, in Short papers in the geologic and hydrologic sciences: U.S. Geol. Survey Prof. Paper 501-C, p. C154-C156.

Czapek, Friedrich, 1905, Biochemie der Pflanzen, v. 2: Jena [Germany], Gustav Fischer, $1026 \mathrm{p}$.

Evans, A. W., 1940, List of Hepaticae found in the United States, Canada, and arctic America : The Bryologist, v. 43, no. 5, p. 133-138.

Garjeanne, A. M. J., 1932, Physiology, in Manual of bryology: The Hague, Martinus Nijhoff, $486 \mathrm{p}$.

Griggs, R. F., 1936, Hepaticae as pioneers on nitrogen-free volcanic ash: Ann Bryologici, v. 8, p. 74-79.

Griggs, R. F., and Ready, Daniel, 1934, Growth of liverworts from Katmai in nitrogen-free media: Am. Jour. Bot., v. 21, no. 5, p. 265-277.

Hutchinson, G. E., 1953, The biogeochemistry of aluminum and of certain related elements: Quart. Rev. Biol., v. 18, p. 1-29, 128-153, 242-262, 331-363.

Kohl, F. G., 1889, Anatomisch-Physiologische Untersuchung der Kalksalze und Kieselsäure in der Pflanze: Marburg, N. G. Elwert'sche Verlagbuchhandlung, $314 \mathrm{p}$.

Lohmann, C. E. J., 1903, Beitrag zur Chemie und Biologie der Lebermoose: Beihefte Bot. Centralbl., v. 15, p. 215-256.

Lounamaa, J., 1956, Trace elements in plants growing wild on different rocks in Finland: Ann. Bot. Soc. Vanamo, v. 29, no. 4, $196 \mathrm{p}$.

Malyuga, D. P., 1964, Biogeochemical methods of prospecting: New York, Consultants Bur., 205 p.

Mayer, A. M., and Gorham, E., 1951, The iron and manganese content of plants present in the natural vegetation of the English Lake District: Ann. Bot. (new ser.) v. 15, no. 58, p. 247-263.

Mitchell, R. L., 1960, Contamination problems in soil and plant analysis: Jour. Sci. Food and Agr., no. 10, p. 553-560. 
Rankama, Kalervo, and Sahama, Th. G., 1955, Geochemistry: Chicago, Univ. Chicago Press, $912 \mathrm{p}$.

Rogina, B., and Dubravcic, M., 1953, Micro-determination of iodides by arresting catalytic reduction of ceric ions : Analyst, v. 78, p. 594.

Salmi, Martti, 1950, Turpeiden Hivenaineista (On trace elements in peat): Geologinen Tutkimuslaitos, Geoteknillisiä julkaisuja, no. 51, $23 \mathrm{p}$.

Schöniger, W., 1955, Rapid microanalytical determination of halogen in organic compounds : Mikrochim. Acta, p. 123-129.

Schroeder, H, A., and Balassa, J. J., 1963, Cadmium-Uptake by vegetables from superphosphate in soil : Science, v. 140, p. 819-920.

Shacklette, H. T., and Cuthbert, M. E., Iodine content of plant groups as influenced by variation in rock and soil type: Geol. Soc. America. (In press.)

Stahl, Ernst, 1888, Pflanzen und Schnecken, eine biologische Studie über die Schutzmittel der Pflanzen gegen Schneckenfrass: Jenaische Zeitschr. Naturw., v. 22, p. 557-684.

Sutcliffe, J. F., 1962, Mineral salts absorption in plants: New York, Pergamon Press, 194 p.

Tamm, C. O., 1953, Growth, yield and nutrition in carpets of a forest moss (Hylocomium splendens) : Medd. från Statens Skogsforskningsinstitut, v. 43 , no. 1,140 p.

Treffner, E., 1881, Beiträge zur Chemie der Laubmoose: Just's Bot. Jahresber., v. 1, p. 157-159.

Waksman, S. A., and Tenney, F. G., 1928, Composition of natural organic materials and their decomposition in the soil, III. The influence of nature of plant upon the rapidity of decomposition: Soil Sci., v. 26, p. 155-171.

Ward, F. N., Lakin, H. W., Canney, F. C., and others, 1963, Analytical methods used in geochemical exploration by the U.S. Geological Survey : U.S. Geol. Survey Bull. 1152, $100 \mathrm{p}$.

Welch, W. H., 1957, Mosses of Indiana : Indianapolis, Ind. The Bookwalter Co., $478 \mathrm{p}$.

Willis, A. J., 1964, Investigations on the physiological ecology of Tortula ruraliformis: British Bryological Soc. Trans., v. 4, pt. 4, p. 668-683.

Zalashkova, N. E., Lizunov, N. V., and Sitnin, A. A., 1958. Essai de leve métallometrique du béryllium dans une zone de pegmatite à béryl recouvertes d'alluvions, in Prospection et Protection du Sous-sol : Service d'Information Geol. B.R.G.G.M. Annales, no. 39, p. 8-13. [Translated from Russian, Razvedka i okhrana nedr, Moscow, August 1958] 


